\title{
Acute aortic dissection in postpartum
}

\author{
Telma Esteves, Lara Caseiro, Ana Codorniz, Fernando Fernandes
}

Hospital do Espirito Santo de Evora EPE, Evora, Portugal

\section{Correspondence to} Dr Telma Esteves, telma.a.esteves@gmail.com

Accepted 26 October 2016

\section{DESCRIPTION}

A Caucasian woman aged 35 years, with no relevant personal history or history of drug abuse and an uneventful pregnancy, presented in the emergency room (ER) at 34 weeks of gestation, with preterm premature rupture of membranes. On physical examination, she had elevated blood pressure and bilateral peripheral oedema. An extensive blood panel was performed, providing the diagnosis of pre-eclampsia. Four hours after admission, she had a vaginal delivery and, 36 hours later, discharged herself against medical advice. A few hours later, she returned to the ER, reporting of severe thoracic pain of sudden onset, sweating and nausea. Her vitals were within normal range, and peripheral pulses were present and symmetrical.

Suspecting a pulmonary embolism, a thoracic CT was performed (figures 1-3), showing 'extensive dissection of the ascending aorta, extending from the aortic root to the origin of the celiac artery. No aneurism is observed'. The patient was transferred to our referral cardiothoracic surgery department, and submitted to an emergency replacement of the

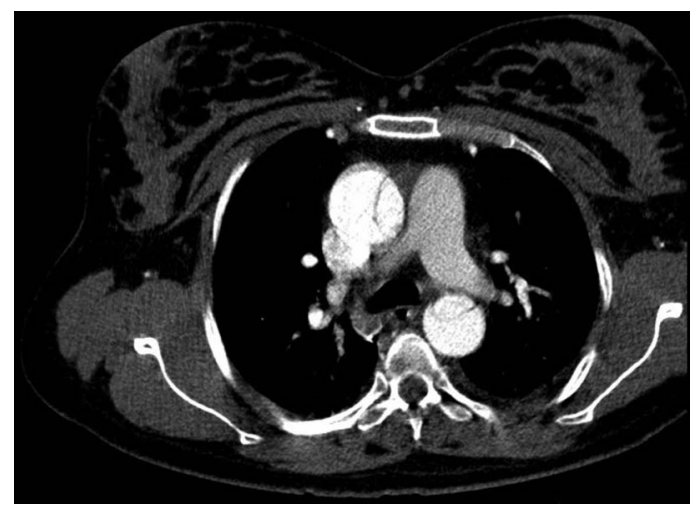

Figure 1 Axial CT image showing an intimal flap that separates the 2 channels in the ascending and descending aorta.

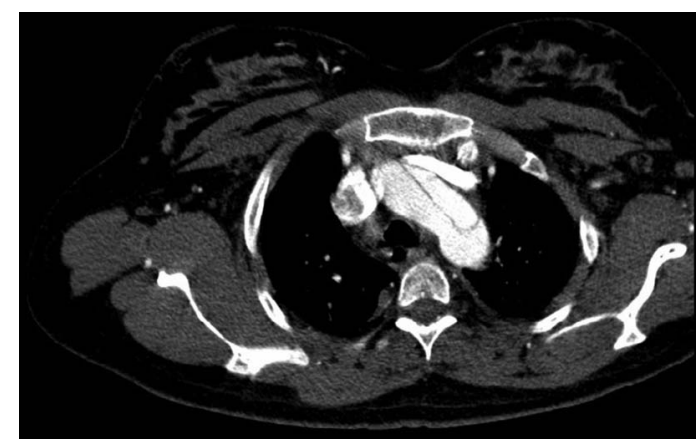

Figure 2 Axial CT image showing the intimal flap in the aorta.

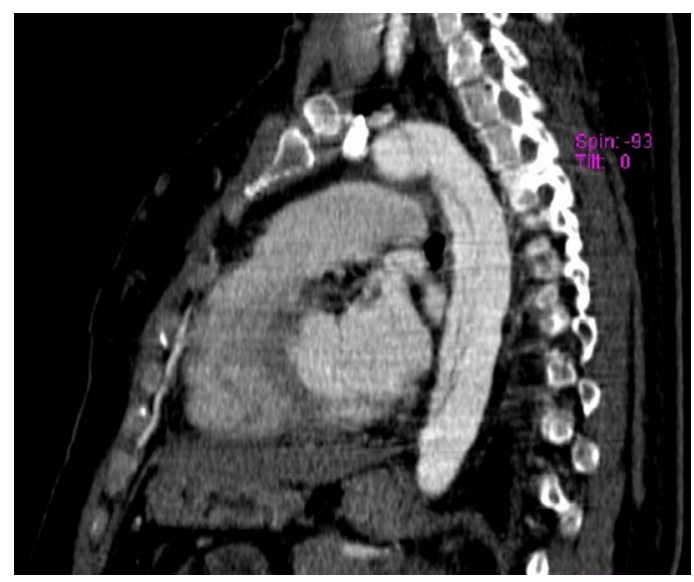

Figure 3 Sagittal CT image, demonstrating the intimal flap in all extension.

aortic root by a tubular prosthesis. The postoperative period was uneventful.

Acute aortic dissection is a rare and lifethreatening condition, which can be presented in different forms and mimic other medical conditions. ${ }^{1}$ Despite its rareness, nearly half of the cases in young women occur during pregnancy, most commonly in the third trimester and peripartum. Since it requires a high level of clinical suspicion, and has an extremely high mortality rate if left untreated, this condition poses an enormous challenge, that obstetricians rarely encounter. ${ }^{23}$

\section{Learning points}

- In women under 40 years, $~ 50 \%$ of all acute aortic dissection (AAD) occur during pregnancy or postpartum.

- Most cases of AAD occur in women with known risk factors (such as Marfan or Turner syndrome), but it can happen in women with no apparent risks.

Contributors TE admitted the patient initially. TE, AC and LC all followed the patient during the hospital stay. TE wrote the initial article, which was then revised by FF.

Competing interests None declared.

Patient consent Obtained.

Provenance and peer review Not commissioned; externally peer reviewed.

\section{REFERENCES}

1 Srettabunjong S. Spontaneous rupture of acute ascending aortic dissection in a young pregnant woman: a sudden unexpected death. Forensic Sci Int 2013;232:e5-8. 
2 Ch'ng S, Cochrane AD, Goldstein J, et al. Stanford type A aortic dissection in pregnancy: a diagnostic and management challenge. Heart Lung Circ 2013:22:12-18
3 Ch'ng S, Cochrane A, Goldstein J, et al. Challenges in the diagnosis and management of Stanford type A dissection in pregnancy. Heart Lung Circ 2011;20:793-4.

Copyright 2016 BMJ Publishing Group. All rights reserved. For permission to reuse any of this content visit http://group.bmj.com/group/rights-licensing/permissions.

BMJ Case Report Fellows may re-use this article for personal use and teaching without any further permission.

Become a Fellow of BMJ Case Reports today and you can:

- Submit as many cases as you like

- Enjoy fast sympathetic peer review and rapid publication of accepted articles

- Access all the published articles

- Re-use any of the published material for personal use and teaching without further permission

For information on Institutional Fellowships contact consortiasales@bmjgroup.com

Visit casereports.bmj.com for more articles like this and to become a Fellow 